\title{
Miniplate 1.5 fixation for the repair of mandibular osteotomies in cats ${ }^{1}$
}

\author{
Fixação interna de osteotomias mandibulares com miniplacas 1.5 em gatos
}

\author{
Adelina Maria da Silva', Wilson Machado de Souza ${ }^{I I}$, Patrícia de Athayde Barnabé ${ }^{I I I}$, Marion Burkhardt de Koivisto ${ }^{\mathrm{IV}}$, Nair \\ Trevizan Machado de Souza ${ }^{\mathrm{V}}$
}

\begin{abstract}
${ }^{1}$ Research performed at Department of Clinics, Surgery and Animal Reproduction, Division of Veterinary Surgical Technique, Sao Paulo State University (UNESP), Araçatuba-SP, Brazil.

${ }^{I} \mathrm{PhD}$, Assistant Professor, Department of Clinics, Surgery and Animal Reproduction, UNESP, Araçatuba-SP, Brazil. Responsible for conception, design, intellectual and scientific content of the study. Acquisition and interpretation of data: surgical procedures and radiographic examinations. Manuscript writing. Statistical analysis.

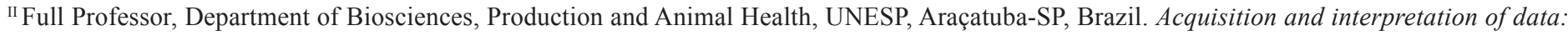
macroscopic and histopathological examinations. Critical revision.

${ }^{\text {III }} \mathrm{PhD}$, DVM, Department of Clinics, Surgery and Animal Reproduction, UNESP, Araçatuba-SP, Brazil. Acquisition and interpretation of data. Histometric examinations.

${ }^{\mathrm{IV}}$ Associate Professor, Department of Clinics, Surgery and Animal Reproduction, UNESP, Araçatuba-SP, Brazil. Acquisition and interpretation of data. Histometric examinations.

${ }^{\mathrm{v}} \mathrm{PhD}$, Zootechnist, Department of Biosciences, Production and Animal Health, UNESP, Araçatuba-SP, Brazil. Acquisition and interpretation of data. Macroscopic and histopathological examinations.
\end{abstract}

\begin{abstract}
Purpose: To evaluate the application of the maxillofacial miniplate 1.5 in the repair of unilateral mandibular osteotomies in cats. Methods: Twelve adult cats were divided into two groups. In group $1(n=6)$, the osteotomy was performed in the body of the mandible, behind the $1^{\text {st }}$ molar. In group $2(n=6)$, the osteotomy was performed between the $4^{\text {th }}$ premolar and $1^{\text {st }}$ molar. The osteotomy was fixed with a titanium miniplate 1.5 . Oral alimentation was reinitiated 24 hours after surgery. Cats were euthanized at 12 weeks postoperative. Results: Radiographs taken 1 week after surgery showed a radiolucent line. The osteotomy line was not more visible on the radiographs taken at 12 weeks postoperative. Macroscopic examination confirmed alignment and bone union of operated hemimandibles. Histological examination showed formation of woven bone within the osteotomy line. The percentage of bone tissue at these areas was measured by the histometry. There was no statistically significant difference between the values of group 1(75.07 \pm 5.99$)$ and group 2 (74.76 \pm 8.54$)$ (Mann-Whitney's test $p=0.469)$. Conclusion: We concluded that the use of miniplate 1.5 for the fixation of mandibular osteotomy in cats provided the main goals in the treatment of mandibular fractures: bone union, normal dental occlusion and immediate return to oral alimentation.
\end{abstract}

Key words: Surgery, Oral. Fracture Fixation, Internal. Mandible. Cats.

\section{RESUMO}

Objetivo: Avaliar a fixação de osteotomias mandibulares unilaterais com miniplacas 1.5 em gatos. Métodos: Foram utilizados 12 gatos adultos divididos em dois grupos de seis animais cada. No grupo 1, a osteotomia foi realizada caudalmente ao $1^{\circ}$ molar e no grupo 2 , entre o $4^{\circ}$ pré-molar e $1^{\circ}$ molar. A osteotomia foi fixada com uma miniplaca 1.5 de titânio. A alimentação oral foi reiniciada 24 horas após a cirurgia. Os animais foram submetidos a eutanásia 12 semanas após a cirurgia. Resultados: A osteotomia pode ser notada como uma linha de radiolucência nas radiografias realizadas uma semana após a cirurgia. Essa linha de radiolucência não foi mais vista nas radiografias realizadas 12 semanas após a cirurgia. No exame macroscópico a hemimandíbula operada apresentava conformação semelhante à hemimandíbula contralateral. A união óssea pode ser confirmada por meio dos exames histológicos que demonstraram a presença de tecido ósseo esponjoso no local da osteotomia. Os exames histométricos demonstraram que não houve diferença estatisticamente significante nos valores observados de porcentagem de tecido ósseo na área de osteotomia das hemimandíbulas operadas dos gatos do grupo $1(75,07 \pm 5.99)$ e grupo $2(74,76 \pm 8,56)$ (Teste de Mann-Whitney p=0,469). Conclusão: Os resultados deste experimento permitiram concluir que a fixação de osteotomias com miniplacas 1.5 em gatos garante os principais objetivos no tratamento de fraturas da mandíbula: união óssea, oclusão dentária normal e alimentação oral imediata.

Descritores: Cirurgia Bucal. Fixação Interna de Fraturas. Mandíbula. Gatos. 


\section{Introduction}

The use of miniplates has revolutionized the treatment of mandibular and maxillofacial fractures in humans. Miniaturized implants are desirable because of the limited surgical field observed in these cases. Besides that, smaller plate systems minimize tissue trauma and facilitates preservation of the periosteal blood supply ${ }^{1-5}$. The crescent clinical application of this method is also observed in small animal surgery ${ }^{6}$.

The objective of this study was to evaluate the use of maxillofacial miniplate 1.5 in the repair of unilateral mandibular osteotomies in cats. We hypothesized that these miniaturized implants could represent a good alternative in the treatment of mandibular fractures in cats.

\section{Methods}

This study was approved by the Ethics Committee for Animal Research of UNESP, Araçatuba-SP, Brazil.

\section{Animals and experimental design}

Twelve healthy young adult (aging between 12 and 36 months) mixed breed cats (weighing $3.1 \pm 0.3 \mathrm{~kg}$ ) were utilized. Six spayed females and 6 neutered males were used and evenly distributed between 2 groups. In group $1(\mathrm{n}=6,3.2 \pm 0.2 \mathrm{~kg})$, the osteotomy was performed in the body of the mandible, behind the $1^{\text {st }}$ molar. In group $2(n=6,3.0 \pm 0.3 \mathrm{~kg})$, the osteotomy was performed between the $4^{\text {th }}$ premolar and $1^{\text {st }}$ molar. The unilateral osteotomy was performed at random in either the right or the left hemimandible. The cats were euthanized at 12 weeks postoperative.

\section{Surgical procedure}

Food was withheld for 12 hours prior to anesthesia. The cats were premedicated with atropine $(0.05 \mathrm{mg} / \mathrm{kg} \mathrm{SC})$, xylazine $(2 \mathrm{mg} / \mathrm{kg} \mathrm{SC})$ and ketamine $(15 \mathrm{mg} / \mathrm{kg}, \mathrm{SC})$. Thiopental $(5 \mathrm{mg} / \mathrm{kg}$ IV) was administered to allow endotracheal intubation. Inhalation anesthesia was maintained with halothane and oxygen. Fentanyl $(0.0125 \mathrm{mg} / \mathrm{kg} \mathrm{IM})$ was administered after anesthesia induction. Lactated Ringer's solution ( $10 \mathrm{ml} / \mathrm{kg}$ IV) was administered throughout anesthesia. Local anesthesia of the inferior alveolar nerve was done with mepivacain $(7 \mathrm{mg} / \mathrm{kg})$ and epinephrine. Ketoprofen $(2 \mathrm{mg} / \mathrm{kg}, \mathrm{SC})$ was administered preoperatively and for 3 days postoperatively. Enrofloxacin $(5 \mathrm{mg} / \mathrm{kg}, \mathrm{SC})$ was administered preoperatively and for 5 days postoperatively.

The cats were positioned in dorsal recumbency. The ventral cranial and cervical regions were clipped, prepared, and draped under sterile technique. A ventral surgical approach to the mandible was performed. The hemimandible was transected transversely. Initially a gap was performed in the cortical bone of the lingual and buccal surfaces and the ventral border with a burr on a low-speed hand-piece under watering. Next, the osteotomy was completed with an osteotome and mallet. The osteotomy was fixed with a 5-hole titanium miniplate 1.5. The miniplate was applied with 4 bicortical screw placement on the ventrobuccal aspect of the hemimandible. Subcutaneous layer was closed with 4-0 polyglactin 910. Skin closure was with 4-0 nylon. Skin sutures were removed after 7 days.

\section{Postoperative observations and radiographs}

Oral alimentation was reinitiated 24 hours after surgery with canned food. This soft food was offered during 3 weeks. After this period, the animals were feed with commercial dry feline diet. Cats were weighted again at the end of the study $(3.2 \pm 0.3 \mathrm{~kg})$

Radiographs were performed one week after surgery and at the end of the study, i.e., after 12 weeks postoperative. The lateral and ventrodorsal views of the mandible were taken. Intraoral radiographs were also performed.

\section{Macroscopic analysis, histolopathology and histometry}

Cats were euthanized at 12 weeks postoperative by intravenous thiopental overdosage. The operated and unoperated hemimandibles of each cat obtained at necropsy were fixed in $10 \%$ formaldehyde solution. Then, each of these hemimandibles was divided longitudinally into two segments. The superior half was demineralised in an aqueous solution of 5.66 formalin $10 \%$ to 1 of nitric acid (v/v). The demineralised specimens were dehydrated in ethanol, clarified in xylol and embedded in paraffin. Thin sections were made and stained with hematoxilin-eosin for microscopic evaluation. The inferior half was processed undecalcified. The undecalcified specimens were dehydrated in ethanol, clarified in xylol and embedded in glycol methacrylate. The thin sections of these specimens were stained with MassonGoldner for microscopic evaluation.

For the histometric analysis, the images of sections were acquired using a digital camera (Olympus DP71) coupled to a microscope (Olympus BX61). The percentage of newly formed bone in the osteotomy area was measured using the Image Pro Plus 6.1 software (Figures 1 and 2). The percentage of bone tissue of unoperated hemimandibles were also measured.

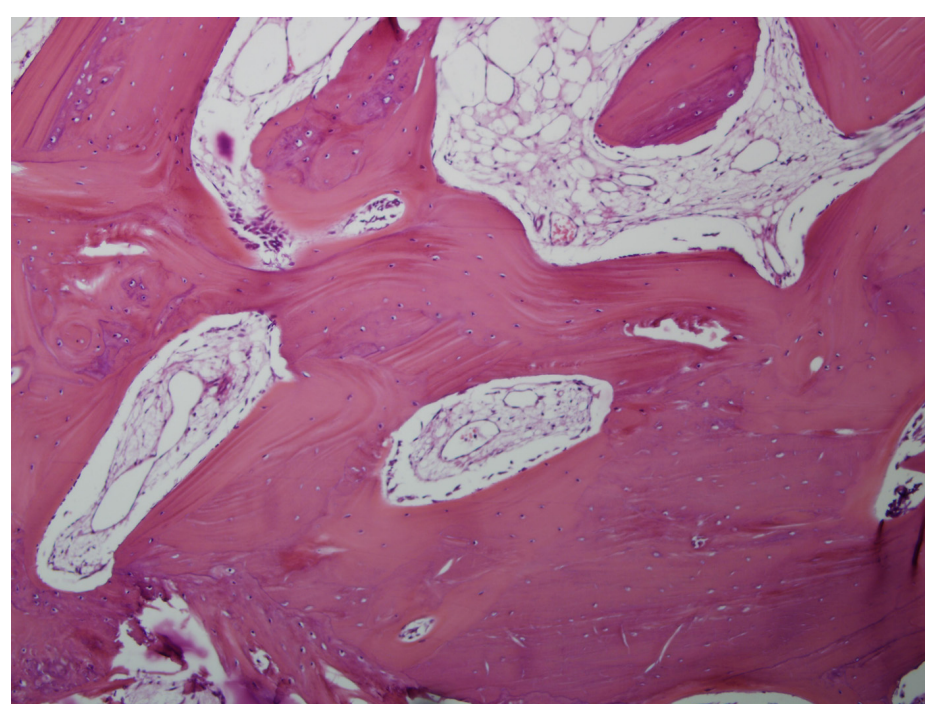

FIGURE 1 - Histologic section of the operated hemimandible of cat 2 of group 1 shows the osteotomy line at 12 weeks postoperative bridged by woven bone. Demineralised bone specimen. (HE -100X) 


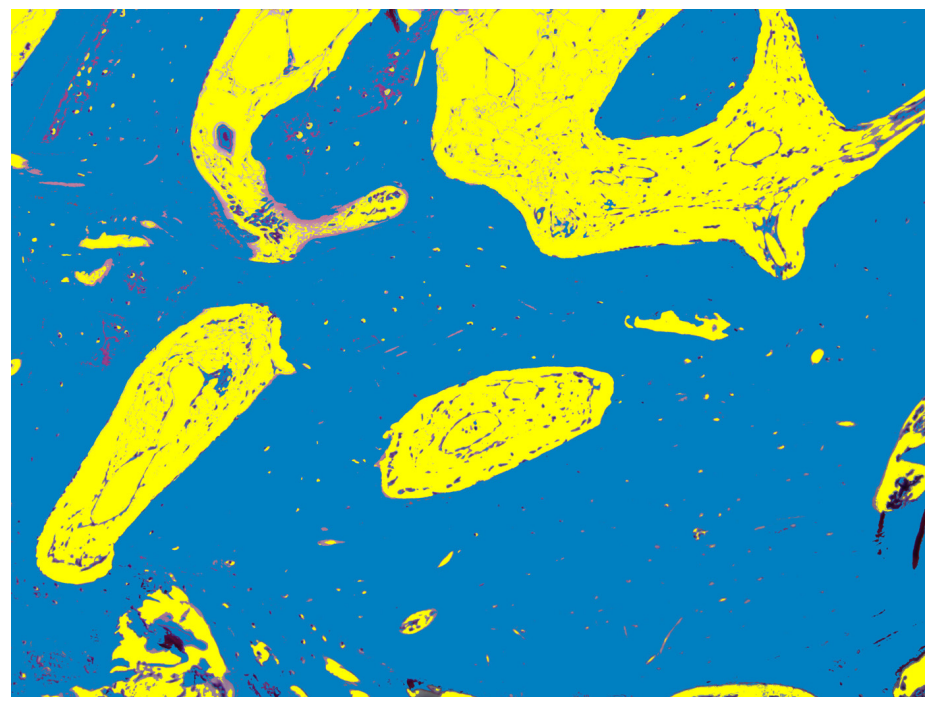

FIGURE 2 - The same histologic section prepared for histometry. The bone tissue was marked in blue and the soft tissue in yellow. Then the percentage of bone tissue was measured using the Image Pro Plus 6.1 software.

\section{Statistical analysis}

Non-parametric tests were utilized for the data analysis, taking into consideration the nature of the variables. Mann-Whitney's test was used to compare histometric data between the two groups. Wilcoxon'test was used to compare histometric data between operated and unoperated hemimandibles. Significance was set at $\mathrm{p}<0.05$.

\section{Results}

There were no clinical complications and the operated hemimandibles healed uneventfully and with appropriate occlusion. During the experimental period the cats showed normal activity and mastication and maintained their initial weight or even gained weight.

Postoperative radiography (intraoral, oblique lateral and ventrodorsal views) was useful in evaluating mandibular alignment and bone healing. Good reduction was obtained and maintained throughout the observation period of 12 weeks and no implant failure occurred. Radiographs taken 1 week after surgery showed a radiolucent line (Figures 3, 4, 5 and 7). The osteotomy line was not more visible on the radiographs taken at 12 weeks postoperative (Figures 6 and 8).

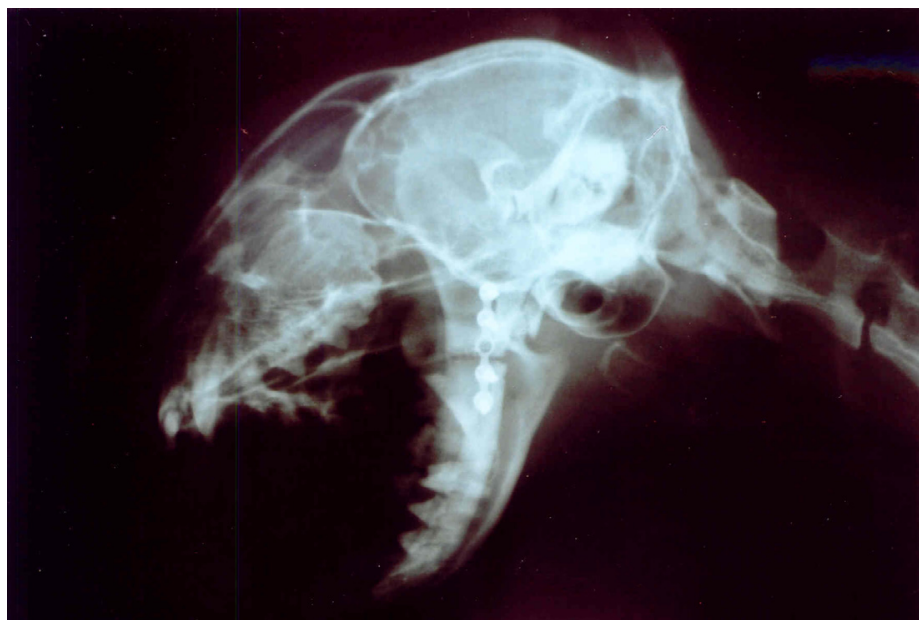

FIGURE 3 - Radiograph in oblique lateral projection taken 1 week after surgery shows the radiolucent line corresponding to the osteotomy. Cat 3 of Group 1.

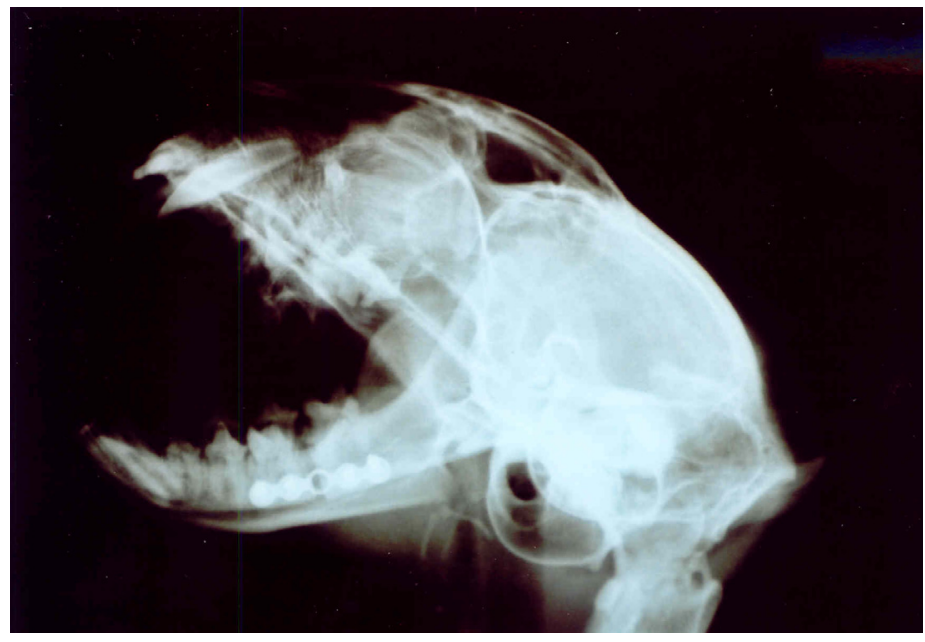

FIGURE 4 - Radiograph in oblique lateral projection taken 1 week after surgery shows the radiolucent line corresponding to the osteotomy. Cat 8 of Group 2.

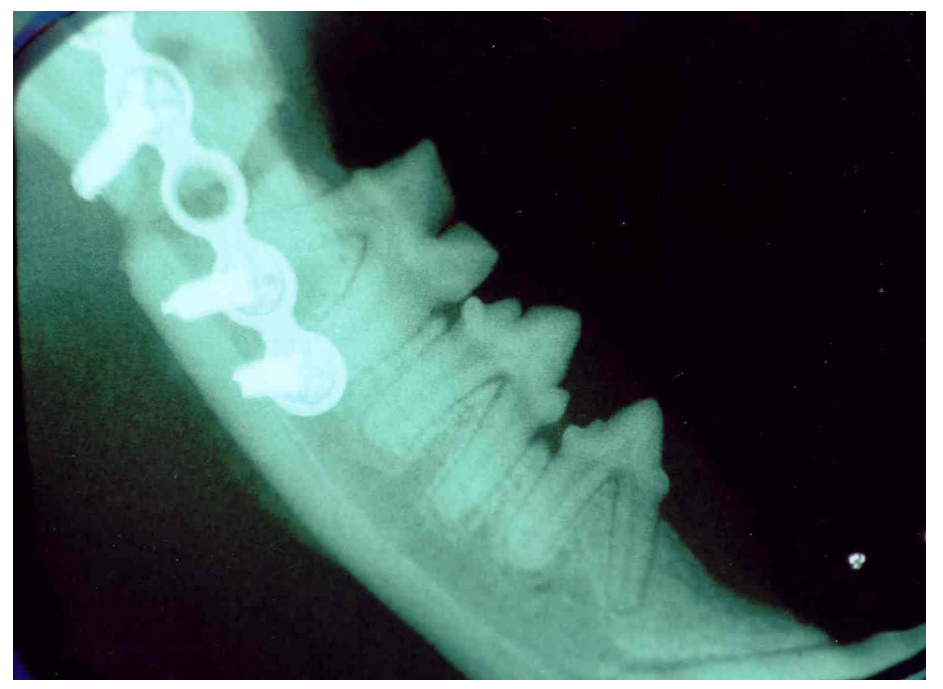

FIGURE 5 - Intraoral radiograph taken 1 week after surgery shows the radiolucent line corresponding to the osteotomy. Cat 5 of Group 1. 


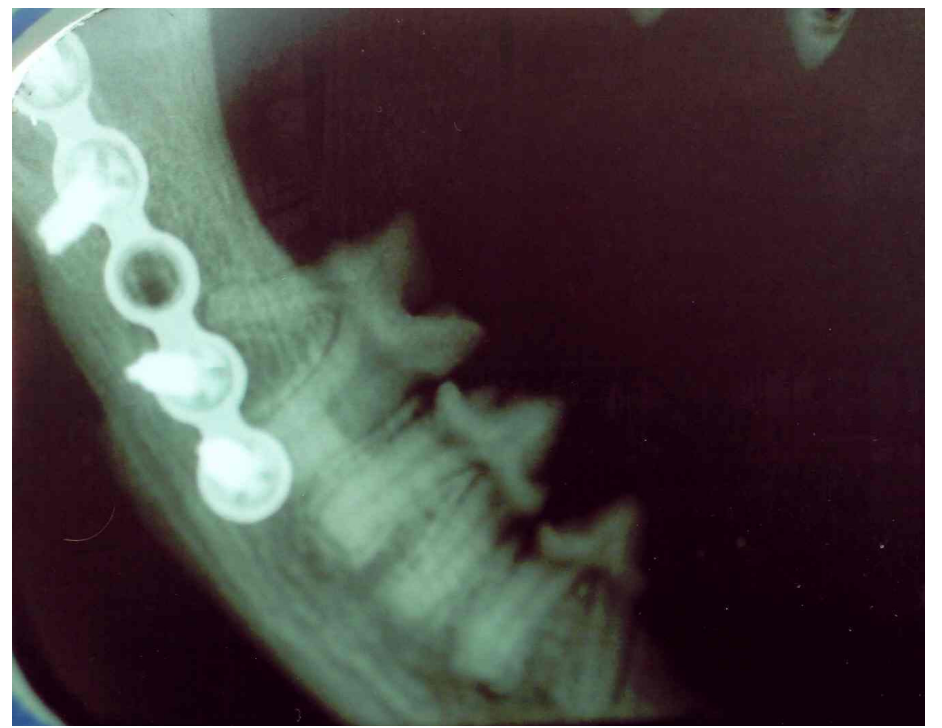

FIGURE 6 - Intraoral radiograph taken 12 weeks after surgery. Bone healing as manifested by obliteration of the osteotomy line. Cat 5 of Group 1.

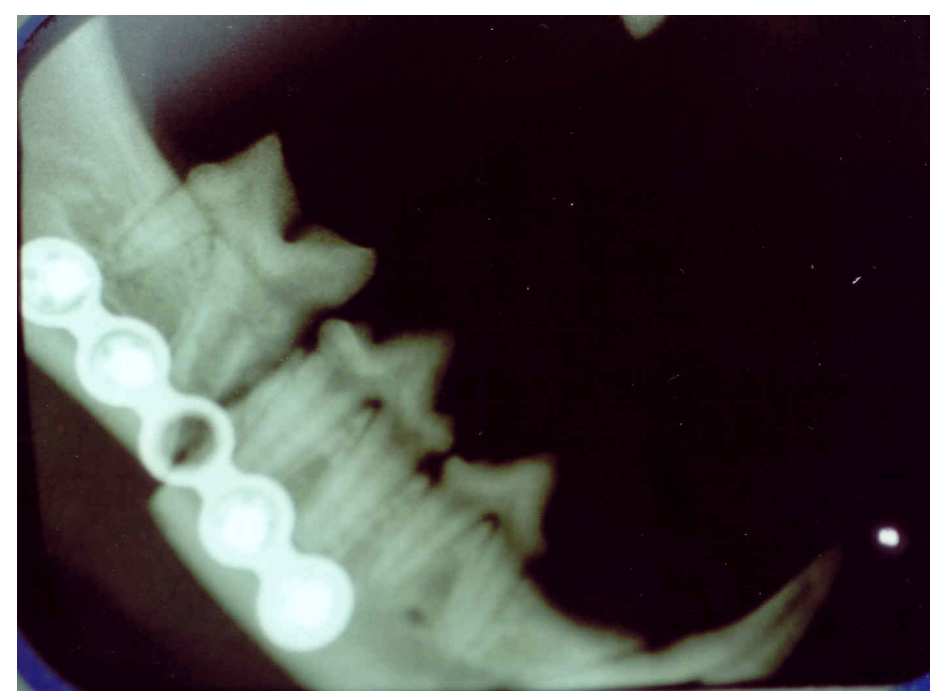

FIGURE 7 - Intraoral radiograph taken 1 week after surgery shows the radiolucent line corresponding to the osteotomy. Cat 10 of Group 2.

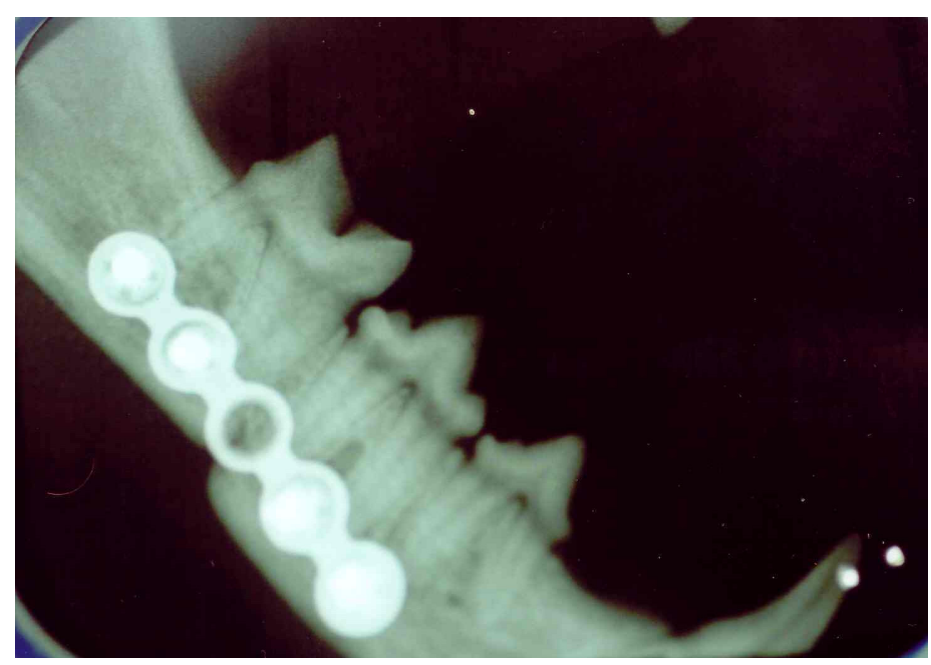

FIGURE 8 - Intraoral radiograph taken 12 weeks after surgery. Bone healing as manifested by obliteration of the osteotomy line. Cat 10 of Group 2.
Macroscopic examination confirmed the alignment and bone union of the operated hemimandibles. Normal dental occlusion was also observed. Histological examination showed that the bone edges created by the osteotomy were linked by woven bone, indicating bone union. The new bone formation almost totally obliterated the mandibular canal adjacent to the osteotomy line (Figures 9 and 10).

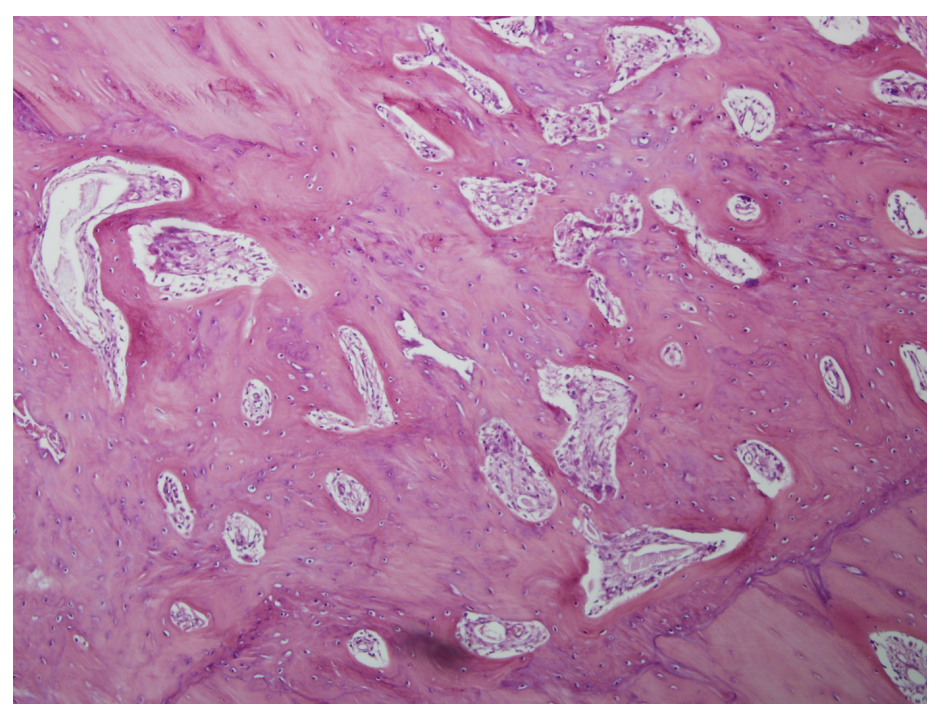

FIGURE 9 - Histologic section of the operated hemimandible shows that the osteotomy line was bridged by woven bone. Cat 3 of Group 1 specimen. (HE - 100X).

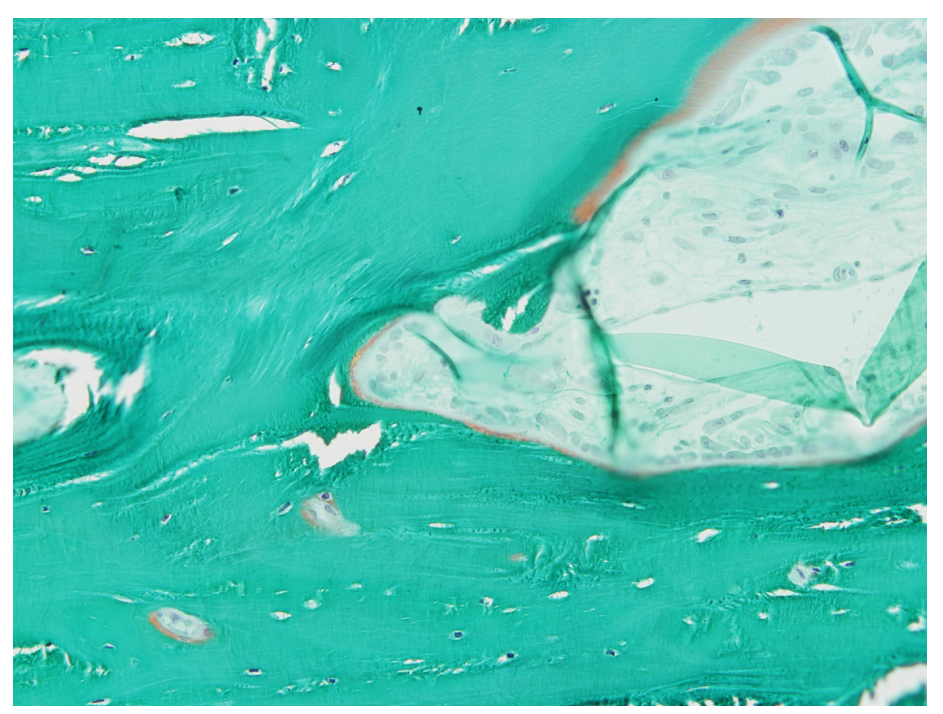

FIGURE 10 - Histologic section of the operated hemimandible shows that the osteotomy line was bridged by woven bone. Mineralised bone: green. Osteoid: orange. Cat 2 of Group 1 specimen. (Masson-Goldner 200X).

The percentage of bone tissue in the area of the previous osteotomy was measured by the histometry. There was no statistically significant difference between the values of group 1 $((75.07 \pm 5.99)$ and group $2(74.76 \pm 8.54)$ (Mann-Whitney's test $\mathrm{p}=0.469)$ (Table 1). These values were smaller from those observed in unoperated hemimandibles (Group 1: $95.80 \pm 2.50 \%$; Group 2: $96.18 \pm 3.09 \%)$. The differences between operated and unoperated hemimandibles were statistically significant (Wilcoxon'test $\mathrm{p}<0.05^{*}$ ) (Tables 2 and 3 ). 
TABLE 1 - Bone fill percentage within the osteotomy line of operated hemimandibles of group 1 and group 2.

\begin{tabular}{lrr}
\hline Statistic & Group 1 & Group 2 \\
& 68.93 & 61.97 \\
& 70.76 & 69.79 \\
& 72.77 & 74.03 \\
& 73.43 & 77.24 \\
& 79.81 & 78.20 \\
Mean & 84.69 & 87.33 \\
Standard deviation & 75.07 & 74.76 \\
Median & 5.99 & 8.54 \\
\hline Mann-Whitney's test & 73.10 & 75.64 \\
\hline
\end{tabular}

TABLE 2 - Bone fill percentage of unoperated and operated hemimandibles of cats of group 1.

\begin{tabular}{cccccc}
\hline Cat $n^{\circ}$ & $\begin{array}{c}\text { Unoperated } \\
\text { heminandible }\end{array}$ & $\begin{array}{c}\text { Operated } \\
\text { hemimandible }\end{array}$ & $d$ & Rank ofd & $\begin{array}{c}\text { Rank with less } \\
\text { frequent sign }\end{array}$ \\
1 & 98.61 & 70.76 & 27.85 & 6 & \\
2 & 93.72 & 79.81 & 13.91 & 1 & \\
3 & 99.23 & 84.69 & 14.54 & 2 & \\
4 & 99.40 & 73.43 & 20.97 & 3 & \\
5 & 93.56 & 68.93 & 24.63 & 5 & \\
6 & 95.25 & 72.77 & 22.48 & 4 & $\mathrm{~T}=0$ \\
\hline
\end{tabular}

TABLE 3 - Bone fill percentage of unoperated and operated hemimandibles of cats of group 2.

\begin{tabular}{cccccc}
\hline Cat $^{\circ}$ & $\begin{array}{c}\text { Unoperated } \\
\text { heminandible }\end{array}$ & $\begin{array}{c}\text { Operated } \\
\text { hemimandible }\end{array}$ & $d$ & Rank ofd & $\begin{array}{c}\text { Rank with less } \\
\text { frequent sign }\end{array}$ \\
7 & 99,16 & 87,33 & 11,83 & 1 & \\
8 & 93,43 & 74,03 & 19,40 & 2 & \\
9 & 98,07 & 77,24 & 20,83 & 3 & \\
10 & 92,20 & 61,97 & 30,23 & 6 & \\
11 & 99,36 & 78,20 & 21,16 & 4 & \\
12 & 94,86 & $\begin{array}{c}69,79 \\
7\end{array}$ & 25,07 & 5 & $\mathrm{~T}=0$ \\
\hline
\end{tabular}




\section{Discussion}

In the present study we used a single miniplate 1.5 applied on the ventrobuccal aspect of the mandible, without damaging the teeth roots. The same technique was adopted by Boudrieau and Kudisch ${ }^{6}$ on the repair of mandibular angle fractures in cats with miniplates 2.0.

In human patients, mandibular angle fractures can be fixed with a single miniplate, but the implant is applied on the alveolar border, which is the ideal line of osteosynthesis in the mandible $e^{1,2,4}$.

Mandibular fractures can also be treated with two miniplates $^{3,7}$. In experimental study with dogs, one miniplate was applied on the ventral border of the mandible with bicortical screws placement and a second miniplate was applied on the alveolar border, with monocortical screws placement to avoid damage to the teeth roots ${ }^{8}$.

A ventral surgical approach to the mandible was used in the present study, as adopted by some experimental studies and clinical reports in dogs and cats ${ }^{6,8,9}$. Contamination seems to be lower in this surgical approach, thereafter a scar in the face doesn't represent an aesthetic prejudice for hairy animals. An intraoral incision is usually preferred in human patients ${ }^{1-4}$.

Our results showed that the application of miniplate provided a fixation stable enough to allow immediate oral alimentation. The cats maintained their initial weight or even gained weight at the end of the present study. Body weight is an important data to be monitored in animals submitted to maxillofacial surgeries ${ }^{9}$.

Postoperative radiography was useful in evaluating hemimandibular alignment and bone healing. Good osteotomy reduction was obtained and maintained throughout the observation period of 12 weeks and no implant failure occurred. Similar results were reported on experimental studies and clinical trials $^{5,6,8}$.

The radiolucent line observed in the immediate postoperative radiographs was not more visible in radiographs taken 12 weeks after surgery, indicating bone healing. But the overlap of cranial bones in oblique lateral and ventrodorsal radiographic views impaired a better visualization of the osteotomy line in some animals. Intraoral radiographs improved the accuracy of the radiographic examination as reported by Kern et al. ${ }^{9}$.

The macroscopic examination confirmed the hemimandibular alignment and bone union. Histological evaluation 12 weeks after surgery showed woven bone within the osteotomy line in the presence of endosteal and periosteal callus. Similar results were reported by Freitag and Landau ${ }^{5}$ in their experimental study in dogs. These authors compared the treatment of mandibular fractures with either a compression plate or a miniplate and observed bone healing at 6-8 weeks after fixation.

With regard to histological and histometric analysis, the present findings are also in agreement with those observed by Sverzut et $a l .{ }^{8}$ Their experimental study in dogs evaluated the bone repair in mandibular osteotomy fixed with two miniplates.
Samples of demineralised bone allowed the preparation of histological sections of approximately $2 \mathrm{~cm}$ in length. Therefore, the area of the osteotomy line bridged by woven bone could be clearly located. Furthermore, there was no significant disruption of the trabecular structure from sectioning as bone trabeculae were thicker after an observation period of 12 weeks. For these two reasons, the sections of demineralised bone embedded in paraffin and stained with hematoxylin-eosin were chosen for the histometric examinations.

As recommended by several authors, it was only possible to obtain histological sections from small samples ( $5 \mathrm{~mm}$ diameter) of undecalcified bone embedded in glycol methacrylate ${ }^{10-13}$. Another factor that contributed to the difficulty in seccioning was the greatest thickness of bone trabeculae after 12 weeks postoperatively. Nevertheless, histological sections were made even from samples of normal hemimandibles formed primarily of compact bone. However, most histological sections showed disruption of bone trabeculae.

Masson-Goldner staining demonstrated clear differentiation between mineralised bone matrix (green) and osteoid (orange), as described by Yang et al. ${ }^{13}$. The discrete presence of osteoid in histological sections of operated hemimandibles, was due to the 12 week observation period, corresponding to a bone union at an advanced stage.

\section{Conclusion}

Based on the results obtained here, it was possible to conclude that the use of miniplate 1.5 for the fixation of mandibular osteotomy in cats provided the main goals in the treatment of mandibular fractures: bone union, normal dental occlusion and immediate return to oral alimentation.

\section{References}

1. Champy M, Loddé JP, Schmitt R. Mandibular osteosynthesis by miniature screwed plates via a buccal approach. J Maxillofac Surg. 1978;6:14-21.

2. Schmelzeisen R, Mciff T, Rahn B. Further development of titanium miniplate fixation for mandibular fractures. Experience gained and questions raised from a prospective clinical pilot study with $2.0 \mathrm{~mm}$ fixation plates. J Craniomaxillofac Surg. 1992;20:251-6.

3. Ellis III E, Walker L. Treatment of mandibular angle fractures using two noncompression miniplates. J Oral Maxillofac Surg. 1994;52:1032-6. 4. Ellis III E, Walker L. Treatment of mandibular angle fractures using one noncompression miniplate. J Oral Maxillofac Surg. 1996;54:864-71.

5. Freitag V, Landau H. Healing of dentate or edentulous mandibular fractures treated with rigid or semirigid plate fixation - an experimental study in dogs. J Craniomaxillofac Surg. 1996;24:83-7.

6. Boudrieau RJ, Kudisch M. Miniplate fixation for repair of mandibular and maxillary fractures in 15 dogs and 3 cats. Vet Surg. 1996;25:277-91. 7. Feller KU, Richter G, Schneider M, Eckelt U. Combination of microplate and miniplate for osteosynthesis of mandibular fractures: an experimental study. Int J Oral Maxillofac Surg. 2002;31:78-83.

8. Sverzut CE, Lucas MA, Sverzut AT, Vieira EH, Trivellato AE, Belti MM, Rosa AL, Oliveira, PT. Bone repair in mandibular body osteotomy after using 2.0 miniplate system Histologic and histometric analysis in dogs. Int J Exp Pathol. 2008;89:91-7. 
9. Kern DA, Smith MM, Stevenson S, Moon M, Saunders GK, Irby MH, Dyer KR. Evaluation of three fixation techniques for repair of mandibular fractures in dogs. J Am Vet Med Assoc. 1995;12:1883-90.

10. Islam A, Frisch B. Plastic embedding in routine histology.I: preparation of semi-thin sections of undecalcified marrow cores. Histopathology. 1995;9:1263-74.

11. Islam A, Henderson S. Glycol methacrylate embedding for light microscopy I enzyme histochemistry on semithin sections of undecalcified marrow cores. J Clin Pathol. 1987;40:1194-200.
12. Wolf E, Röser K, Hahn M, Welkerling H, Delling G. Enzyme and immunohistochemistry on undecalcified bone and bone marrow biopsies after embedding in plastic: a new embedding method for routine application. Virchows Archiv A Pathol Anat Histopathol. 1992;420:17-24.

13. Yang R, Davies CM, Archer CW, Richards RG. Immunohistochemistry of matrix markers in technovit 9100 new $^{\circledR}$ embedded undecalcified bone sections. Eur Cell Mater. 2003;6:57-71.

\section{Correspondence:}

Adelina Maria da Silva

Univ. Estadual Paulista-UNESP

Depto. Clínica Cirúrgica e Reprodução Animal

Rua Clóvis Pestana, 793

16050-680 Araçatuba - SP Brasil

Phone: (55 18)3636-1404

adelinasilva@uol.com.br

Received: July 21, 2010

Review: September 15, 2010 Accepted: October 19, 2010 